\title{
SIRPB1 wt Allele
}

National Cancer Institute

\section{Source}

National Cancer Institute. SIRPB1 wt Allele. NCI Thesaurus. Code C51032.

Human SIRPB1 wild-type allele is located within 20p13 and is approximately $57 \mathrm{~kb}$ in length. This allele, which encodes signal-regulatory protein beta-1 protein, is involved in the negative regulation of receptor tyrosine kinase-coupled signaling processes. 